\author{
Magdalena Ossowska \\ Uniwersytet Warszawski \\ ORCID: https://orcid.org/0000-0001-7255-2590 \\ m.ossowska1307@gmail.com
}

\title{
Pytanie o dopuszczalność substytucji powierniczej a projekt prawa spadkowego autorstwa Stanisława Wróblewskiego
}

\author{
The Question of the Admissibility of Fideicommissary Substitution \\ and the Stanisław Wróblewski's Inheritance Law Draft
}

\section{STRESZCZENIE}

W artykule zostało omówione zagadnienie substytucji powierniczej w kontekście projektu prawa spadkowego autorstwa S. Wróblewskiego. W pracy opisano znaczenie metody historycznoporównawczej dla oceny współczesnych rozwiązań w polskim Kodeksie cywilnym z 1964 r. Przybliżono też historię instytucji podstawienia powierniczego oraz jej zakazu, a także podano argumenty używane w dyskusji nad dopuszczalnością tej instytucji. Ponadto wskazano poszczególne postanowienia projektu S. Wróblewskiego odnoszące się do podstawienia powierniczego.

Słowa kluczowe: substytucja powiernicza; warunek; prawo cywilne; prawo spadkowe; testament

Jeżeli ocenialibyśmy kodyfikację prawa spadkowego w II Rzeczypospolitej tylko przez pryzmat zazwyczaj pożądanych od tego procesu rezultatów, nie można by było zaliczyć jej do udanych - prace podkomisji prawa spadkowego nie doprowadziły do wydania aktu unifikującego prawo odradzającej się Rzeczypospolitej. Opracowanie takiego aktu prawnego okazało się niemożliwe ze względu na specyfikę prawa spadkowego, tak silnie związanego z uwarunkowaniami społecznymi i kulturowymi danego społeczeństwa ${ }^{1}$, a także z powodu niestabilnego składu

1 Leonard Górnicki przytacza celne słowa Fryderyka Zolla: „Prawa osobowe, rodzinne, rzeczowe i spadkowe wiążą się może najsilniej z naturą ludzką, wnikają głęboko w serca i umysły społeczeństwa i w jego interesy społeczne i ekonomiczne, a prawa państw zaborczych, różniące się w tych kierunkach wybitnie między sobą, wyżłobiły w ciągu półtorawiekowej naszej niewoli tak 
podkomisji prawa spadkowego. W latach 1919-1939, w których działała Komisja Kodyfikacyjna, zmieniał się bowiem w szczególności referent podkomisji prawa spadkowego, a wraz z nim koncepcja całego projektu kodyfikacji tej gałęzi prawa ${ }^{2}$. Mimo to do wybuchu II wojny światowej udało się Komisji Kodyfikacyjnej opracować pewne podstawowe założenia prawa spadkowego, zasady ogólne. Projekty Henryka Konica i Stanisława Wróblewskiego oraz późniejsze prace Kazimierza Przybyłowskiego były inspiracją i nieocenioną pomocą dla powojennych kodyfikatorów ${ }^{3}$. Moim zdaniem oddziaływanie dorobku przedwojennej cywilistyki jednak nie kończy się w momencie opracowania ustawy, przeciwnie - także dziś można odnaleźć w tych projektach wiele oryginalnych myśli, które okazują się cennym materiałem do badań historycznoporównawczych. Powodzenie kodyfikacji czy też fakt obowiązywania danego kodeksu nie wpływa na jego wartość do badań nad kształtem prawa współczesnego.

Za przykład niech posłuży projekt S. Wróblewskiego, wybitnego polskiego romanisty i cywilisty, referenta podkomisji prawa spadkowego w latach 1934-1938, autora m.in. komentarza do austriackiego prawa spadkowego z 1904 r., aktywnego członka utworzonej w 1919 r. Komisji Kodyfikacyjnej, w której prace angażował się bardzo intensywnie. Wróblewski miał swój znaczący udział w sekcji prawa handlowego, podkomisji części ogólnej prawa cywilnego; zajmował się w ramach Komisji również prawem wekslowym i czekowym, prawem międzydzielnicowym, międzynarodowym prawem prywatnym ${ }^{4}$. Jako referent podkomisji prawa spadkowego opracował „ważniejsze zasady”, na których miał się opierać jego projekt, zaś w listopadzie 1937 r. pierwszą część projektu5, której zakres objął dwa działy

wybitne odrębności w naszych poglądach etycznych, politycznych i gospodarczych, że próby usuwania tych odrębności - choćby na razie tylko w drodze jednolitego ustawodawstwa - natrafiały nieraz na silny opór i przeszkody. O ileż łatwiejsza była unifikacja np. prawa handlowego, wekslowego, czekowego, zobowiązań, prawa międzynarodowego prywatnego, autorskiego, patentowego itp., które są instytucjami o charakterze raczej międzynarodowym, niewykazującymi istotnych różnic w ustawach państw cywilizowanych". Zob. L. Górnicki, Prawo cywilne w pracach Komisji Kodyfikacyjnej Rzeczypospolitej Polskiej w latach 1919-1939, Wrocław 2000, s. 479. Zob. również: F. Longchamps de Bérier, Law of Succession. Roman Legal Framework and Comparative Law Perspective, Warszawa 2011, s. 24.

L. Górnicki, Prawo cywilne..., s. 310-311.

3 Zob. K. Sójka-Zielińska, Historia prawa, Warszawa 2009, s. 228-230; K. Przybyłowski, Polskie międzywojenne prace kodyfikacyjne w dziedzinie prawa spadkowego, [w:] Księga pamiatkowa ku czci Kamila Stefki, Warszawa-Wrocław 1967, s. 269.

4 Wkład S. Wróblewskiego w prace Komisji Kodyfikacyjnej opisuje L. Górnicki (Działalność Stanisława Wróblewskiego w Komisji Kodyfikacyjnej Rzeczypospolitej Polskiej, [w:] Stanisław Wróblewski 1868-1938. Materiały z posiedzenia naukowego w dniu 21 listopada 2008 r., red. A. Mączyński, Kraków 2011, s. 79-119).

5 Niestety, zachowało się do tego dzieła tylko opracowanie Kazimierza Przybyłowskiego. Zob. L. Górnicki, Prawo cywilne..., s. 295. 
tytułu pierwszego dotyczącego powołania do spadku6. Pod wieloma względami autor odwołał się w nich do rzymskiej myśli prawnej, z której dorobku chętnie korzystał w badaniach prawnoporównawczych ${ }^{7}$.

Dla Wróblewskiego drogą do rozważań nad prawem współczesnym było prawo rzymskie. W art. 54a projektu ${ }^{8}$ Wróblewski uregulował, w ślad za rzymskimi Digestami ${ }^{9}$, klasyczny problem rzymskiego prawa spadkowego dotyczący warunku zawieszającego potestatywnego ujemnego (tzw. cautio Muciana) ${ }^{10}$; opowiadał się raczej za instytucją zachowku, a nie chroniącą w większej mierze interesy rodziny rezerwą. Gorąco spierał się też o miejsce dziedziczenia testamentowego w systematyce kodeksu - miało ono wyprzedzać drugorzędne dziedziczenie $a b$ intestato $^{11}$. Według Wróblewskiego to właśnie testament, jako najwyższy wyraz autonomii woli spadkodawcy ${ }^{12}$, powinien górować nad zastępczymi regułami dziedziczenia ustalanymi przez ustawodawcę ${ }^{13}$. Ze ściśle rzymskiej swobody testowania wyrastała również dozwolona w ogólnych zasadach projektu - jako podlegająca przepisom o warunkowym ustanowieniu spadkobiercy - substytucja powiernicza (fideikomisarna) ${ }^{14}$.

Łagodne zapatrywania Wróblewskiego odnośnie do powoływania dziedzica pod warunkiem lub z ustanowieniem terminu prezentują się na tle współcześnie funkcjonujących rozwiązań niezwykle oryginalnie - wszak takie dyspozycje, jak substytucja powiernicza, są de lege lata niedozwolone w polskim Kodeksie cywilnym z 1964 r. Dzisiaj, w obliczu postępujących zmian w stosunkach społecznych i gospodarczych dokonujących się w 100 lat po odzyskaniu przez Polskę niepodległości, należy zastanowić się, czy wytworzone w minionej epoce rozwiązania odpowiadają współczesnym wymaganiom ludzi. W kontekście dyskusji nad rolą

${ }^{6}$ Dział pierwszy obejmował przepisy ogólne o spadku, tytułach powołania, o chwili i skuteczności powołania. Dział drugi nie został ukończony - odnosił się do testamentu, ustanowienia dziedzica, warunku, terminu i zlecenia. Zob. K. Przybyłowski, op. cit., s. 263.

7 F. Longchamps de Bérier, Stanisław Wróblewski o znaczeniu wpływu prawa rzymskiego na prawo współczesne, [w:] Stanisław Wróblewski1868-1938. Materiały..., s. 35.

8 Art. 54a: Warunek, że powołany w ogóle nie uczyni czegoś, co zawisło jedynie od jego woli, jest warunkiem rozwiązującym, który uzależnia bezskuteczność powołania od dokonania przez powołanego czynności warunkiem określonej. Zob. K. Przybyłowski, op. cit., s. 268.

9 D. $35,1,73$.

10 W. Dajczak, T. Giaro, F. Longchamps de Bérier, Prawo rzymskie. U podstaw prawa prywatnego, Warszawa 2012, s. 125. Konstrukcję tę można odnaleźć także we współczesnych kodyfikacjach cywilnych. Por. § 2075 kodeksu cywilnego niemieckiego i art. 638-639 kodeksu cywilnego włoskiego.

11 K. Przybyłowski, op. cit., s. 268.

12 Słowami jurysty Ulpiana (D. 34, 4, 4): Testamentum ambulatoria est enim voluntas defuncti usque ad vitae supremum exitum (,Testament zmienną jest bowiem wolą zmarłego aż do samego kresu życia").

13 L. Górnicki, Działalność Stanisława Wróblewskiego..., s. 93.

14 K. Przybyłowski, op. cit., s. 262. 
i znaczeniem omawianej instytucji prawa spadkowego doniosłość jubileuszu każe się uważniej przyjrzeć dorobkowi przedwojennego cywilisty.

W pierwszej kolejności należy przybliżyć historię i konstrukcję prawną substytucji powierniczej. Jest to jedna z odmian podstawienia, wyróżniana tradycyjnie obok substytucji zwykłej, zachodzącej, gdy inna osoba nie chce lub nie może przyjąć spadku. Podstawienie powiernicze polega natomiast na zobowiązaniu osoby, której przypadły dobra spadkowe, do zachowania nabytego spadku i pozostawienia go innej osobie. Dziedzic jest w tym przypadku związany wolą spadkodawcy na jedno lub więcej pokoleń, gdyż musi pozostawić majątek wskazanemu w testamencie substytutowi ${ }^{15}$. Podstawiona osoba może już, jako sukcesor uniwersalny, swobodnie rozporządzać majątkiem spadkowym. W przypadku bardziej złożonych, wielokrotnych podstawień, za pomocą których testator wskazywał kolejnych członków jednej familii, dane dobra majątkowe mogły być utrzymywane w rękach jednej grupy osób przez wiele dekad. Na takiej zasadzie opierała się konstrukcja fideikomisu familijnego, która przyznawała testatorowi bardzo daleko idące uprawnienie do decydowania o swoim majątku po śmierci, sięgające nawet kilka pokoleń naprzód ${ }^{16}$.

Substytucje wywodzą się ze starożytnego Rzymu, a dokładniej z fideikomisu uniwersalnego, który uzyskał zaskarżalność najprawdopodobniej już w 15. roku przed Chrystusem, za czasów Oktawiana Augusta. Dzięki zastosowaniu tej konstrukcji prawnej spadkodawca osiągał skutki czasowego ustanowienia dziedzica - spadkobierca bowiem stawał się swego rodzaju powiernikiem mającym zachować i przekazać otrzymany spadek innej osobie ${ }^{17}$. Takie rozrządzenie stwarzało możliwość niezwykle zręcznego dysponowania swoim majątkiem i oddawało w większym stopniu wyraz woli testatora. Elastyczność to niewątpliwie zaleta tej instytucji; substytucja fideikomisarna pozwala na dokonywanie bardziej wyszukanych dyspozycji - tak, aby jak najpełniej zrealizować oczekiwania testatora co do pozostawionego przez niego spadku ${ }^{18}$. W końcu spadkodawca może mieć interes w przekazaniu dziedzicowi majątku po upływie określonego czasu, chcąc zmobilizować substytuta do podjęcia określonych działań (np. ukończenia nauki w szkole). Można sobie również wyobrazić sytuację, w której spadkodawca pragnie wyrazić wdzięczność danej osobie, umożliwiając jej czasowe korzystanie ze spadku. Dzięki bardziej złożonym dyspozycjom, uwzględniającym wielokrotne podstawienia, spadkodawca może zadbać o zabezpieczenie dóbr rodzinnych przed

15 K. Osajda, Komentarz do art. 962-964, [w:] Kodeks cywilny. Komentarz, t. 3: Spadki, red. K. Osajda, Warszawa 2013, s. 461-472.

16 F. Longchamps de Bérier, Podstawienie powiernicze, „Kwartalnik Prawa Prywatnego” 1999, nr 2, s. 324-328.

17 Ibidem, s. 327.

18 Idem, O elastyczność prawa spadkowego. Fideikomis uniwersalny w klasycznym prawie rzymskim, Warszawa 2006, s. 178-180. 
ich marnotrawieniem i rozdrobnieniem ${ }^{19}$. Nie można więc dziwić się popularności substytucji powierniczej ${ }^{20}$, która w takiej czy nieco zmienionej formie występuje w ustawodawstwach na kontynencie europejskim ${ }^{21}$.

Wobec tego wypada zastanowić się nad pobudkami, które przesądziły o zakazie substytucji fideikomisarnej we współczesnym prawie polskim. Jak wynika z powyższych rozważań, prawu rzymskiemu nie był znany zakaz substytucji. Jest to wymysł doktryny francuskiej i właśnie z Francji przywędrował do polskiego Kodeksu cywilnego. We Francji fideikomis (jak nazywano wówczas nowy rodzaj substytucji - substytucję powierniczą) pojawił się w XII w. i szybko zdobył popularność - tak dużą, że w okresie poprzedzającym rewolucję francuską 95\% nieruchomości we Francji było wyjęte z obrotu ze względu na objęcie ich fideikomisami $^{22}$. Z tego powodu francuski ustawodawca zadecydował w art. 896 Kodeksu Napoleona, że „substytucje są zakazane" ${ }^{23}$. Zakaz ten niewątpliwie był wynikiem pewnych określonych uwarunkowań ideologicznych omawianego okresu - feudalna instytucja, która pozwalała arystokracji na wręcz wieczyste posiadanie własności, stała w wyraźnej opozycji do haseł głoszących liberalizm ekonomiczny i zniesienie przywilejów w dziedziczeniu, zasadzający się na umożliwieniu jak najszerszego zbywania dóbr przez najzdolniejsze podmioty. Również czysto praktyczne względy przesądziły o niedopuszczalności substytucji. Powoływanie dziedzica pod warunkiem lub z oznaczeniem terminu zawsze niesie za sobą ryzyko powstania niepewności co do stosunków własnościowych ${ }^{24}$, co jest kluczowe zwłaszcza w przypadku obrotu nieruchomościami.

Pewien wyjątek od omawianego zakazu w 1807 r. wymogła na francuskim ustawodawcy instytucja majoratów - wielkoobszarowych, niepodzielnych i niezbywalnych majątków ziemskich, na które składały się dobra stanowiące uposażenie tytułu dziedzicznego nadanego przez cesarza ${ }^{25}$. Zakaz taki nie mógł się przyjąć także w prawie polskim, w którym od wieków istniały ordynacje rodowe. Zdaniem

19 J. Wierciński, Uwagi o zakazie podstawienia powierniczego, „Przegląd Sądowy” 2011, nr 5, s. 106.

${ }^{20}$ Na marginesie warto zauważyć, że instytucja fideikomisu uniwersalnego łagodziła skutki dość dużego sformalizowania rzymskiego prawa spadkowego. Poza utrzymywaniem pewnych składników majątkowych w ramach jednej rodziny, korzystanie z fideikomisów pozwalało na faktyczne omijanie prawa (np. lex Voconia, zabraniający żonom i córkom nabywania majątku w drodze dziedziczenia; por. ibidem) czy omijania zakazów dziedziczenia (np. wyzwoleńców). Można więc uznać, że w momencie powstania konstrukcja ta miała odpowiadać wymaganiom ówczesnych ludzi, których potrzeby dotyczące rozrządzania majątkiem nie mogły być efektywnie spełniane jedynie za pomocą instytucji dawnego ius civile.

21 F. Longchamps de Bérier, Podstawienie..., s. 328-331.

22 Ibidem, s. 105-108.

${ }^{23}$ Ibidem, s. 331. Substytucje fideikomisarne zostały zniesione dekretami Konwentu już w 1792 r.

24 Ibidem; J. Wierciński, op. cit., s. 107.

25 F. Longchamps de Bérier, Podstawienie..., s. 331. 
Franciszka Longchamps de Bériera ordynacje „stanowily najsilniej zakorzeniony w polskiej tradycji prawnej przejaw akceptacji podstawienia powierniczego"26. Mimo to trzeba przyznać, że istniało ich stosunkowo niewiele ${ }^{27}$, lecz utrzymały się długo, gdyż w większości aż do XX w. ${ }^{28}$ Po I wojnie światowej obowiązujące na ziemiach odrodzonej Rzeczypospolitej regulacje pozwalały na utrzymywanie dotychczasowych ordynacji, jednak bez możliwości tworzenia nowych ${ }^{29}$.

Biorąc pod uwagę inne ustawodawstwa obowiązujące wówczas na terenie Rzeczypospolitej, należy przyznać, że substytucje w ogólności były dopuszczalne, ale nie wszędzie w pełnym zakresie. W Zwodzie Praw było dozwolone podstawienie zwykłe, jednak nie powiernicze (t. X, cz. 1, art. 1011); podobnie rzecz wyglądała w Kodeksie Napoleona ${ }^{30}$, gdzie ponadto dopuszczono pewne wyjątki, np. dodatek do art. 896 z 1807 r. dotyczący tworzenia majoratów. Niemiecki kodeks cywilny (BGB) i austriacki kodeks cywilny (ABGB) dopuszczały obie formy substytucji (§ 2103-2105, 2108-2109, 2162-2163, 2177-2179, 2191 BGB oraz § 604-607, 615 i 608-617 ABGB). Jeżeli chodzi o warunek i termin, to odnaleźć go można w kodeksach: francuskim (art. 1040-1041 i $900 \mathrm{KN}$ ), austriackim (§ 695-708 ABGB) i niemieckim (§ 2103-2105, 2108-2109, 2162-2163, 2177-2179, 2191 BGB), natomiast $\mathrm{z}$ art. 1011 t. X, cz. 1 Zwodu Praw wyinterpretowano dopuszczalność wyłącznie warunków zawieszających ${ }^{31}$. Widać zatem, że dopuszczenie warunkowego powołania dziedzica czy - szerzej - dopuszczenie dyspozycji testamentowej, jaką jest substytucja powiernicza, prawdopodobnie nie jawiłoby się jako instytucja egzotyczna i nieprzystająca do polskiego prawa prywatnego, w jego tradycji funkcjonowały bowiem instytucje o charakterze powierniczym.

Jak już wcześniej zaznaczono, zakaz substytucji fideikomisarnych obowiązuje w obecnym stanie prawnym. Kwestię podstawienia powierniczego rozstrzyga art. 964 Kodeksu cywilnego ${ }^{32}$, który przewiduje co najwyżej konwersję tego rozrządzenia w podstawienie zwykłe. Zakaz podstawień powierniczych wywodzi się też

26 Ibidem, s. 333.

27 Do najbardziej znanych polskich ordynacji można zaliczyć ordynacje Radziwiłłów, Zamoyskich, Myszkowskich i Ostrogskich. Zob. M. Kuryłowicz, Zapis uniwersalny i podstawienie powiernicze (uwagi historycznoprawne), „Rejent” 1991, nr 6, s. 39.

28 T. Zielińska, Ordynacje w dawnej Polsce, „Przegląd Historyczny” 1977, t. 68, s. 17-30.

29 F. Longchamps de Bérier, Podstawienie..., s. 334.

30 Zakaz substytucji powierniczych był wyrażony w art. 896, natomiast substytucje zwykłe były dozwolone w art. 898 .

31 Analizy ustawodawstw dokonał wnikliwie L. Górnicki (Prawo cywilne..., s. 299).

32 Ustawa z dnia 23 kwietnia 1964 r. - Kodeks cywilny. (Dz.U. z 1964 r., nr 16, poz. 93). Art. 964: Postanowienie testamentu, przez które spadkodawca zobowiązuje spadkobiercę do zachowania nabytego spadku i do pozostawienia go innej osobie, ma tylko ten skutek, że ta inna osoba jest powołana do spadku na wypadek, gdyby spadkobierca nie chciał lub nie mógł być spadkobiercą. Jeżeli jednak z treści testamentu lub z okoliczności wynika, iż spadkobierca bez takiego ograniczenia nie byłby powołany, powołanie spadkobiercy jest nieważne. 
tradycyjnie z uregulowań zabraniających powoływania dziedzica pod warunkiem lub z zastrzeżeniem terminu (art. 962), czyli tak, jak w fideikomisach. O takim kształcie regulacji kodeksowej zaważyły przede wszystkim argumenty ideologiczne - wszak instytucja prawna sprzyjająca gromadzeniu znacznych majątków była nie do pogodzenia z prawem socjalistycznym ${ }^{33}$. Współcześnie wysuwa się w doktrynie kilka zasadniczych argumentów przeciwko dopuszczalności substytucji powierniczej.

Pierwszym z nich jest wspomniana wyżej groźba wyjęcia danego składnika majątkowego z obrotu na długi czas - w końcu, stosując substytucję, ograniczamy rozporządzalność danych dóbr do momentu spełnienia się zdarzenia, z którym łączy się, zgodnie z dyspozycją spadkobiercy, przejście wspomnianego składnika majątku na dziedzica (substytuta). Rozpatrując kwestię substytucji fideikomisarnej, należy jednak stwierdzić, że ów zarzut nie jest do końca trafiony. W przypadku podstawienia powierniczego możliwość swobodnego rozrządzania rzeczą jest przywrócona już w momencie wydania spadku substytutowi, zatem czas, na który dane dobro majątkowe jest ,zatrzymane” w jednych rękach, jest relatywnie krótki. Problematyczna jest również kwestia statusu prawnego spadku przed realizacją podstawienia - jak się wskazuje, nieznana jest prawu polskiemu konstrukcja własności podzielonej ${ }^{34}$. Bez szczegółowych uregulowań ustawowych korzystanie z podstawień powierniczych byłoby niekorzystne z punktu widzenia przejrzystości obrotu, co jest kluczowe we współczesnych stosunkach gospodarczych, wymagających pewności co do stosunków własnościowych. Zdaje się, że obecnie kwestię tę $\mathrm{w}$ zadowalającym stopniu rozwiązuje instytucja ksiąg wieczystych. Ciekawy zarzut przedstawiła też Elżbieta Skowrońska-Bocian ${ }^{35}$, podnosząc, że spadek byłby niewłaściwie administrowany w rękach osób, które zaraz miałyby się go wyzbyć. Niemniej ustawodawstwa, w których dozwala się na podstawienia powiernicze, nakładają jednocześnie na powiernika obowiązek starannego działania w celu zachowania substancji majątku ${ }^{36}$.

Jak widać, argumenty, które są często używane w dyskusji nad dopuszczalnością substytucji powierniczej, wymagają głębszego rozważenia. Prawdą jest, że w latach 60. ubiegłego wieku, w momencie tworzenia obecnego Kodeksu cywilnego, część z nich mogła mieć wymierne znaczenie, obecnie jednak prawo spadkowe przestaje odpowiadać oczekiwaniom społecznym dotyczącym możliwości dysponowania

33 M. Kuryłowicz, op. cit., s. 39-40; F. Longchamps de Bérier, Podstawienie ..., s. 336-340.

34 K. Osajda, op. cit., s. 459-461. Zob. także: E. Skowrońska-Bocian, Testament w prawie polskim, Warszawa 2004, s. 148-150.

${ }^{35}$ Ibidem.

36 Na przykład regulacja szwajcarskiego kodeksu cywilnego (ZGB) - art. 488-492. Zob. W. Dajczak, T. Giaro, F. Longchamps de Bérier, op. cit., s. 300. 
majątkiem mortis causa ${ }^{37}$. Rozważając reformę tej gałęzi prawa prywatnego, nie wolno ignorować dorobku intelektualnego najznakomitszych przedstawicieli nauki, do których bez cienia wątpliwości można zaliczyć S. Wróblewskiego.

W ,ważniejszych zasadach”, na których miał bazować projekt Wróblewskiego, czytamy: ,[...] tzw. podstawienie powiernicze podlega przepisom o powołaniu warunkowym lub terminowym, wymaga jednak ustawowego uregulowania stosunków prawnych spadku w okresie przed spełnieniem się warunku lub nadejściem terminu". Materię warunkowego powołania dziedzica regulował natomiast art. 53 $\S 1$ projektu $^{38}$. Wróblewski dostrzegał więc problemy, jakie mogą wynikać ze stosowania konstrukcji czasowego powołania spadkobiercy - zdawał sobie sprawę z faktu, że stosowanie tej konstrukcji prawnej może prowadzić do niepewności w stosunkach majątkowych.

Niepewność ta z dogmatycznego punktu widzenia sprowadza się do dylematu, czy mamy w przypadku substytucji powierniczej do czynienia z dwoma dziedzicami. Kwestia ta nie została, jak sobie tego życzył autor projektu, uregulowana ustawowo $^{39}$. Zawiłości substytucji powierniczej Wróblewski tłumaczył wnikliwie na przykładzie austriackiego prawa spadkowego ${ }^{40}$. Biorąc pod uwagę niebywałą biegłość Wróblewskiego w stosowaniu metody prawnoporównawczej, można pokusić się o postawienie hipotezy, że broniłby swojej koncepcji dotyczącej substytucji powierniczej, odnosząc się właśnie do austriackiego kodeksu cywilnego - jako profesor Uniwersytetu Jagiellońskiego był przecież siłą rzeczy pod wpływem austriackiej myśli prawnej ${ }^{41}$.

W swoich badaniach Wróblewski doszedł do wniosku, że osoba zarządzająca spadkiem nie ma statusu dziedzica, ale jest swego rodzaju użytkownikiem spadku ${ }^{42}$.

37 Por. A. Moszyńska, Prawo spadkowe w Polsce w latach 1918-1964 - główne postulaty badawcze, „Z Dziejów Prawa” 2014, nr 7, s. 243-255; F. Longchamps de Bérier, Podstawienie..., s. 323-324.

38 „Spadkodawca może powołać dziedzica pod warunkiem zawieszającym lub rozwiązującym”. Treść projektu i ,zasad ogólnych” przytacza K. Przybyłowski (op. cit., s. 261-268).

39 Niestety, śmierć referenta projektu 18 grudnia 1938 r. przeszkodziła w opracowaniu jakichkolwiek szczegółowych rozwiązań tej kwestii.

40 S. Wróblewski, Komentarz do $\$$ 531-824 austryackiego kodeksu cywilnego (prawo spadkowe), Kraków 1904, s. 193 i n.; idem, Podstawienie powiernicze, „Czasopismo Prawnicze i Ekonomiczne" 1903, s. 494-534.

41 Zob. S. Grodziski, Profesor Stanisław Wróblewski w Radzie Wydziału Prawa Uniwersytetu Jagiellońskiego, [w:] Stanisław Wróblewski 1868-1938. Materiały ..., s. 62-68.

42 S. Wróblewski, Komentarz..., s. 199: „Pierwszy dziedzic jest tedy tylko użytkowcą aktywów spadkowych, którego prawo traktuje formalnie na równi z dziedzicem i któremu na czas użytkowania powierza zastępstwo spadku”. Podobnie: „Powiernik przy warunkowem podstawieniu powierniczem jest tedy jako taki tylko użytkowcą spadku, którym równocześnie jako kurator zarządza. Jeżeli spadek dostanie się później dziedzicowi warunkowemu, okaże się zarazem, iż poprzednio nie było dziedzica, że więc prawo utrzymywało majątek bez podmiotu ze względu na jego przeznaczenie, podobnie jak utrzymuje majątek przy fundacyi. Jeżeli zaś powiernik jest także pospolicie podstawiony 
Co ciekawe, koncepcja ta jest polemiczna w stosunku do głosów doktryny austriackiej z przełomu XIX i XX w. ${ }^{43}$ Według Wróblewskiego nie można w przypadku podstawienia powierniczego przyjąć, że spadkodawca ustanowił dwóch dziedziców, gdyż tylko w stosunku do substytuta nastąpi przejście własności w kształcie przysługującym spadkodawcy, natomiast osoba zobowiązana do wydania spadku substytutowi nabywa inne prawo niż prawo własności. Jak twierdził: „[...] własność dopuszcza czasowych ograniczeń (iura in re) i przez to własnością być nie przestaje, własność jednak z zakreślonym czasem trwania do nazwy własności nie ma prawa, i tylko za czasowe ograniczenie innej (prawdziwej) własności stanowić może" ${ }^{4}$. Kontynuując swój wywód z założeniem, że tak naprawdę nie powołano dwóch spadkobierców, Wróblewski w złożony, lecz klarowny sposób wyjaśnił, jak mogą się kształtować stosunki majątkowe do momentu ziszczenia się warunku czy też nadejścia terminu ${ }^{45}$.

Podsumowując, można powiedzieć, że kodyfikacji prawa spadkowego w II Rzeczypospolitej towarzyszył zbieg niefortunnych okoliczności. Ta silnie zespolona z uwarunkowaniami kulturowymi dziedzina prawa nie została potraktowana przez Komisję Kodyfikacyjną w sposób priorytetowy; zmiany personalne w podkomisji doprowadziły do tego, że wysiłek jej członków dzielił się przez liczbę opracowanych projektów. Obowiązujące wówczas ustawodawstwa państw zaborczych stworzyły obiecującą podstawę do budowy nowoczesnych, elastycznych uregulowań dotyczących dziedziczenia. $Z$ drugiej strony ustrój socjalistyczny po II wojnie światowej skutecznie przeciwstawił się dopuszczeniu substytucji powierniczej ${ }^{46}$. Dzisiaj, w stulecie odzyskania niepodległości, nasza rzeczywistość wypełnia się nowymi zjawiskami, z którymi prawo musi się prędzej czy później zmierzyć. Zalicza się do nich globalizację, europeizację prawa prywatnego, dekodyfikację ${ }^{47}$. Trzeba w związku z tym dopuścić do siebie myśl, że i prawo spadkowe ulegnie w tej nowej rzeczywistości zmianie. Rozważania dotyczące reform prawa spadkowego powinny uwzględnić rozwiązania znane europejskiej tradycji prawnej, a zarzucone w pewnym momencie historii, np. takie, jak substytucja powiernicza. Czy w takim razie sensowny jest powrót do rozwiązań z czasów II Rzeczypospolitej, które - podobnie jak prawo rzymskie - nie mają już żadnej mocy obowiązującej?

fideikomsaryuszowi, a podstawienie powiernicze upadnie, wówczas prawo przyjmuje, iż powiernik był dziedzicem już od chwili śmierci spadkodawcy, choć na razie nie było jeszcze wiadomem, iż spadek na niego przeszedł" (idem, Podstawienie..., s. 521-522).

43 Idem, Komentarz..., s. 192 i n.

44 Ibidem, s. 194.

45 Idem, Komentarz..., s. 193 i n.; idem, Podstawienie..., s. 494 i n.

46 F. Longchamps de Bérier, Podstawienie..., s. 338.

47 T. Giaro, Moment historyczny w prawoznawstwie prawnoporównawczym, [w:] Prawo obce w doktrynie prawa polskiego, red. A. Wudarski, Warszawa 2016, s. 43-62. Zob. także: Dekodyfikacja prawa prywatnego. Szkice do portretu, red. F. Longchamps de Bérier, Warszawa 2017. 
Sam Wróblewski wierzył, że niesie to za sobą wartość. Podkreślał: „„[...] przez to odpada niebezpieczeństwo, grożące każdej teorii opartej na gruncie prawa obowiązującego, w której pod wpływem znaczenia praktycznego normy pozytywnej zbyt łatwo przecenić jej doniosłość i zapomnieć o tym, że to tylko jedna $\mathrm{z}$ wielu możliwości” ${ }^{48}$. Jak wiele istnieje tych możliwości, może nam to uzmysłowić tylko historia prawa.

\section{BIBLIOGRAFIA}

Dajczak W., Giaro T., Longchamps de Bérier F., Prawo rzymskie. U podstaw prawa prywatnego, Warszawa 2012.

Dekodyfikacja prawa prywatnego. Szkice do portretu, red. F. Longchamps de Bérier, Warszawa 2017.

Giaro T., Moment historyczny w prawoznawstwie prawnoporównawczym, [w:] Prawo obce w doktrynie prawa polskiego, red. A. Wudarski, Warszawa 2016.

Górnicki L., Działalność Stanisława Wróblewskiego w Komisji Kodyfikacyjnej Rzeczypospolitej Polskiej, [w:] Stanisław Wróblewski 1868-1938. Materiaty z posiedzenia naukowego $w$ dniu 21 listopada 2008 r., red. A. Mączyński, Kraków 2011.

Górnicki L., Prawo cywilne w pracach Komisji Kodyfikacyjnej Rzeczypospolitej Polskiej w latach 1919-1939, Wrocław 2000.

Grodziski S., Profesor Stanisław Wróblewski w Radzie Wydziału Prawa Uniwersytetu Jagiellońskiego, [w:] Stanisław Wróblewski 1868-1938. Materiaty z posiedzenia naukowego w dniu 21 listopada 2008 r., red. A. Mączyński, Kraków 2011.

Kuryłowicz M., Zapis uniwersalny i podstawienie powiernicze (uwagi historycznoprawne), „Rejent” $1991, \mathrm{nr} 6$.

Longchamps de Bérier F., Law of Succession. Roman Legal Framework and Comparative Law Perspective, Warszawa 2011.

Longchamps de Bérier F., O elastyczność prawa spadkowego. Fideikomis uniwersalny w klasycznym prawie rzymskim, Warszawa 2006.

Longchamps de Bérier F., Podstawienie powiernicze, „Kwartalnik Prawa Prywatnego” 1999, nr 2.

Longchamps de Bérier F., Stanisław Wróblewski o znaczeniu wpływu prawa rzymskiego na prawo współczesne, [w:] Stanisław Wróblewski 1868-1938. Materiały z posiedzenia naukowego w dniu 21 listopada 2008 r., red. A. Mączyński, Kraków 2011.

Moszyńska A., Prawo spadkowe w Polsce w latach 1918-1964-główne postulaty badawcze, „Z Dziejów Prawa" 2014, nr 7.

Osajda K., Komentarz do art. 962-964, [w:] Kodeks cywilny. Komentarz, t. 3: Spadki, red. K. Osajda, Warszawa 2013.

Przybyłowski K., Polskie międzywojenne prace kodyfikacyjne w dziedzinie prawa spadkowego, [w:] Ksiega pamiatkowa ku czci Kamila Stefki, Warszawa-Wrocław 1967.

Skowrońska-Bocian E., Testament w prawie polskim, Warszawa 2004.

Sójka-Zielińska K., Historia prawa, Warszawa 2009.

Ustawa z dnia 23 kwietnia 1964 r. - Kodeks cywilny (Dz.U. z 1964 r., nr 16, poz. 93).

Wierciński J., Uwagi o zakazie podstawienia powierniczego, „Przegląd Sądowy” 2011, nr 5.

48 S. Wróblewski, Posiadanie na tle prawa rzymskiego, Kraków 1899, s. 11. 
Pobrane z czasopisma Studenckie Zeszyty Naukowe http://szn.umcs.pl

Data: 26/04/2023 12:37:50

Pytanie o dopuszczalność substytucji powierniczej a projekt prawa spadkowego...

Wróblewski S., Komentarz do §§ 531-824 austryackiego kodeksu cywilnego (prawo spadkowe), Kraków 1904.

Wróblewski S., Podstawienie powiernicze, „Czasopismo Prawnicze i Ekonomiczne” 1903.

Wróblewski S., Posiadanie na tle prawa rzymskiego, Kraków 1899.

Zielińska T., Ordynacje w dawnej Polsce, „Przegląd Historyczny” 1977, t. 68.

\section{SUMMARY}

The article discusses the issue of fideicommissary substitution in the light of the Stanisław Wróblewski's inheritance law draft. The importance of the historical-comparative method for the evaluation of contemporary solutions in the Polish Civil Code of 1964 was described. The history of fideicommissary substitution and prohibition of this legal institution was presented, as well as the arguments used in the discussion on the admissibility of this institution. Moreover, particular legal provisions of the S. Wróblewski' draft law concerning fideicommissary substitution were indicated.

Keywords: fideicommissary substitution; condition; civil law; inheritance law; will 